\title{
From Theoretical To Practical: Developing Tillich's Apologetics
}

\author{
Wendy Morrison \\ Boston College School of Theology and Ministry
}

Paul Tillich's understanding of faith, doubt, and church communities forms part of a systematic theology which Tillich understands as a theoretical apologetics. By developing these themes, especially Tillich's concept of existential doubt, five guidelines for a practical apologetics can be developed in line with Tillich's theoretical apologetics. First, both believers and nonbelievers are included in the apologist's audience because both are at risk of idolatry. Second, the goal of apologetics is to end the suppression of doubt in order to break down idols. Third, this apologetics affirms faith without aiming to rid one of doubt. Fourth, apologetics should bring Christians and non-Christians into faith communities. Fifth, those faith communities should continue the work of apologetics by remaining open to doubt. These guidelines form a method of apologetics that speaks to the increasing secularity of the world. By breaking down traditional categories which separate faith from doubt and believers from nonbelievers, this practical apologetics is capable of moving people toward a deeper, more dynamic faith in the True God.

Wendy Morrison completed her Master of Theological Studies in May 20211 with a concentration in systematic theology from the Boston College School of Theology and Ministry. She is currently an intern at the Theology and Ministry Library and a member of the student forum. In the fall, Wendy will attend Loyola University Chicago for the Integrative Studies in Ethics and Theology PhD program with a concentration in theology. 


\section{Introduction}

For decades now people have been talking about the increasing secularity of the world and even the increasing secularity of the church. Theologian Paul Tillich stated in 1945 that "it is a well-known fact that this process of secularization has affected all of the great religions." Donald G. Bloesch, the late professor of theology at Dubuque Theological Seminary, gave a similar analysis 23 years later, when he said, "What makes our situation different from that of other ages is that the church itself is becoming secular. The need in our time is not only to reclaim the world for the Gospel but also to reconvert large segments of the church itself."2 While secularity is by no means a new phenomenon, it is a persistent one that has not lost its fervor in recent years nor ceased challenging the mission of the church. As an answer to this challenge, Paul Tillich takes an apologetic approach to theology. By uncovering the theoretical apologetics embedded throughout his writings, five guidelines for a practical apologetics will be developed. This paper will first examine Tillich's understanding of faith, doubt, apologetics, and church communities. Five guidelines for a practical apologetics based on these principles will then be suggested.

\section{Tillich On Faith And Doubt}

\section{Faith}

Put most simply, the goal of apologetics is to provide a convincing argument for faith in God. However, Tillich's understanding of faith differs from the common understanding. In fact, he introduces Dynamics of Faith by saying, "There is hardly a word in the religious language, both theological and popular, which is subject to more misunderstandings, distortions and

\footnotetext{
${ }^{1}$ Paul Tillich, The World Situation (1945; repr., Philadelphia: Fortress Press, 1965), 42.

${ }^{2}$ David G. Bloesch, The Christian Witness in a Secular Age: An Evaluation of Nine Contemporary Theologians (Minneapolis: Augsburg Publishing House, 1968), 28.
} 
questionable definitions than the word 'faith.",3 Therefore, a careful reading of Tillich's understanding of the word is essential.

Interestingly, while Tillich states that "there is as yet no substitute expressing the reality to which the term 'faith' points," he does go on to suggest a new term - ultimate concern. People have many concerns, but can only have one ultimate concern. One's ultimate concern gives life meaning and affects the whole person, and when one experiences the presence of one's ultimate concern, it is felt as the presence of the holy. ${ }^{5}$ Tillich explains that if a concern "claims ultimacy it demands the total surrender of him who accepts this claim, and it promises total fulfillment even if all other claims have to be subjected to it or rejected in its name."6 Although Tillich claims that everyone has an ultimate concern, he does not imply that everyone has the same ultimate concern or that one's ultimate concern is God. One makes a god out of her ultimate concern, but that god is not necessarily God. One's ultimate concern could instead be success, one's nation, or pleasure; the content does not need to be ultimate to be the object of ultimate concern. Therefore, since "faith is the state of being ultimately concerned,", everyone has faith. This is precisely where Tillich's understanding of faith diverges from the common understanding of the word. While it is logical to say the content of one's faith has changed, for Tillich, it is illogical to speak of losing one's faith. Losing one's faith would mean one is not ultimately concerned about anything, but such an extreme apathy is almost a contradiction in terms. One who attempts "extreme apathy" is likely to discover that apathy itself has become one's ultimate concern.

\footnotetext{
${ }^{3}$ Paul Tillich, Dynamics of Faith (New York: Harper \& Row, 1957), xxi.

${ }^{4}$ Ibid.

5 Ibid., 13.

${ }^{6}$ Ibid., 1.

${ }^{7}$ Ibid., 4.
} 
To further clarify his definition of faith, Tillich distinguishes between faith and belief. Tillich makes this clarification because he finds, "The most ordinary misinterpretation of faith is to consider it an act of knowledge that has a low degree of evidence." 8 This, Tillich explains, should rightly be referred to as belief. We believe things when we trust the authority they come from, despite the fact that we do not have firsthand experience of the evidence. Therefore, we believe scientific theories, and we believe the biblical witnesses. We do not have faith in them, however. Faith involves “participation in the subject of one's ultimate concern with one's whole being."9 A Christian should only be ultimately concerned with God; therefore, a Christian should only claim faith in God. As Catholic theologian Raymond Smith explains, "Tillich's notion of faith is really an insistence that God, and not a list of doctrines, is the object of faith." ${ }^{10}$

Some theologians, including Smith, object to such a strict separation between belief and faith. Smith argues that for Catholics, obedience to the Catholic Church is not seen as contrary to faith. He writes, "If the teachings of the Church are correctly understood, her dogmas are not meant to take man away from God, but to lead man to God, forever grateful for the teachings of the Bible which do provide us with much information on God and his providence over mankind." Smith worries that Tillich may be "throwing the baby out with the bath water" when he dismisses the value of any authority. Smith writes, "Faith as including a list of beliefs need not be condemned outright simply because, on the natural level, some political system, such as Communism, proposes class hatred, or, on the supernatural plane, some individuals use religion as an excuse to suppress others."12 Yet, in Tillich's own writing he does not suggest that

\footnotetext{
${ }^{8}$ Ibid., 31 .

${ }^{9}$ Ibid., 32.

${ }^{10}$ Raymond Smith O. P., "Faith Without Belief," in Paul Tillich in Catholic Thought, ed. Thomas A. O'Meara and Celestin D. Weisser (Dubuque: The Priory Press, 1964), 138.

${ }^{11}$ Smith, "Faith Without Belief," 142.

12 Ibid., 141.
} 
people should not have beliefs. He only wishes to distinguish those beliefs as secondary to one's ultimate concern; they are not essential to faith in God.

\section{Doubt}

Essential to Tillich's understanding of faith, and his understanding of apologetics, is the concept of doubt. Like faith, the word doubt is used in several different contexts. Tillich identifies three uses of doubt which he calls methodological, skeptical, and existential. The final type of doubt, existential doubt, is the most important for Tillich's theology. Existential doubt is "implicit in every act of faith."13 This is possible because of Tillich's distinction between faith and belief. Tillich writes, "If faith is understood as belief that something is true, doubt is incompatible with the act of faith. If faith is understood as being ultimately concerned, doubt is a necessary element in it." ${ }^{, 14}$ Doubt is necessary when one is ultimately concerned because one can never know whether the content of one's ultimate concern is truly ultimate. There is always a nagging feeling that perhaps life really has no meaning and nothing is ultimate. Arne Unhjem calls this "radical doubt" and defines it as "the recognition—often implicit, rather than explicit— that there is no truth and no meaning that deserves man's unqualified acceptance."15 Yet, "The brink of despair toward which the doubter is driven is also the frontier of hope, for it is here that the meaning of existence may be recovered and the power of life restored."16 Existential doubt is the realization that one's god may not be God, but it is precisely this realization that moves one toward God and out of complacency. Therefore, no one would be capable of moving toward faith in God without existential doubt.

\footnotetext{
${ }^{13}$ Tillich, Dynamics of Faith, 20.

${ }^{14}$ Ibid., 18.

15 Arne Unhjem, Dynamics of Doubt: A Preface to Tillich (Philadelphia: Fortress Press, 1966), 50.

${ }^{16}$ Ibid., 44.
} 


\section{The Risk Of Faith: Idolatry}

Existential doubt introduces an element of risk in faith which must be matched by a complementary element of courage. The risk is that the content of one's ultimate concern might break down. If one's ultimate concern “proves to be a failure, the meaning of one's life breaks down; one surrenders oneself, including truth and justice, to something which is not worth it.",17 Faith must have courage to accept the uncertainty. ${ }^{18}$ Mary Ann Stenger explains the relationship between courage and doubt saying, "Courage in faith does not repress doubt but includes it as an awareness of the risk of faith, the element of 'in spite of', taking seriously the experience of doubt. Recognizing that such a view counters a traditional view of faith as without doubt or tensions, Tillich argues that the traditional view is non-dynamic, even 'dead'."19 Tillich's notion of faith is certainly not static. Faith is continually challenged by existential doubt and accepted again through courage.

The dynamic nature of faith serves as a protection against idolatry. Existential doubt causes one to question whether one's ultimate concern is actually ultimate. Frank D. Rees writes, "The more idolatrous a faith, the less it is able to overcome the 'cleavage' between subject and object and thus to convince people that its object is indeed ultimate. Idolatrous faith breaks down, while faith in the genuinely ultimate succeeds in 'relating' us to our ultimate concern." ${ }^{20}$ Since a person places her whole being in the hope that her idol is ultimate, the exposure of the idol is always a traumatic event. Although losing a belief may be difficult, it is nothing compared with discovering one's faith is directed toward an idol. Tillich writes, “The

\footnotetext{
${ }^{17}$ Tillich, Dynamics of Faith, 17.

18 Ibid., 16.

${ }^{19}$ Mary Ann Stenger, "Faith (and Religion)," in The Cambridge Companion to Paul Tillich, ed. Russell Re Manning (Cambridge: Cambridge University Press, 2009), 95-96.

${ }^{20}$ Frank D. Rees, Wrestling With Doubt: Theological Reflections on the Journey of Faith (Collegeville: The Liturgical Press, 2001), 85.
} 
inescapable consequence of idolatrous faith is 'existential disappointment,' a disappointment which penetrates into the very existence of man!"21 Yet, this despair can be a moment of hope, because, for Tillich, one always has faith. In the moment of existential disappointment, one's faith is not lost. Rather, one has the opportunity to redirect one's faith to something better able to withstand the demands of ultimacy.

Non-Christians are not the only ones at risk of idolatrous faith. Even Christians, who claim to have faith in God, can begin to cling to more accessible symbols of God rather than to God in God's self. Tillich writes, "Faith, if it takes its symbols literally, becomes idolatrous! It calls something ultimate which is less than ultimate. Faith, conscious of the symbolic character of its symbols, gives God the honor which is due him." 22 In order to prevent idolatrous faith among Christians, Tillich introduces the Protestant principle. The Protestant principle, as defined by Unhjem, is “the spiritual law that all finite expressions of man's experience of God must be negated if they are not to become idolatrous distortions, and that only in this way can they be affirmations of God."23 Tillich, expressing his frustration with the Catholic Church, explains the purpose of the Protestant principle this way, "The Protestant principle is the restatement of the prophetic principle as an attack against a self-absolutizing and, consequently, demonically distorted church." 24 The prophetic principle to which Tillich refers is simply that the prophet points to God but is not God. Likewise, the Protestant principle declares that although the church provides a way of experiencing God, it is not God. Tillich is concerned that Catholics have made the declarations of the Catholic Church into their god, when no declaration can ever encompass who God is. One need not understand the Protestant principle as specific to

\footnotetext{
${ }^{21}$ Tillich, Dynamics of Faith, 12.

22 Ibid., 52.

${ }^{23}$ Unhjem, Dynamics of Doubt, 118.

${ }^{24}$ Paul Tillich, Systematic Theology Volume One (Chicago: University of Chicago Press, 1951), 227.
} 
Protestants, however. Surely both Protestants and Catholics are guilty of idolatry. Furthermore, Tillich's insight that God cannot be fully possessed or described is not a new insight. On the contrary, it dates back long before the existence of Protestants in the traditions of apophatic prayer and negative theology. Nevertheless, "Protestant principle" is the term Tillich chooses to use, and, consequently, it is the term this paper will use.

\section{Pastoral Issues}

To conclude this section on Tillich's understanding of faith and doubt, two pastoral issues must be addressed. First, one must answer to those who have faith but do not feel doubt. Second, one must clarify what is actually happening when someone says they have lost their faith, if faith is impossible to lose. The first issue Tillich addresses easily. He uses anxiety as an analogy for the way doubt works. Tillich describes anxiety as the awareness of one's finitude. Although one may not always feel anxiety, the condition of one's anxiety (finitude) always exists. $^{25}$ Likewise, "doubt is not a permanent experience within the act of faith. But it is always present as an element in the structure of faith." 26

Tillich responds to the second issue by restating his position that doubt is not synonymous with loss of faith. He writes, "Many Christians, as well as members of other religious groups, feel anxiety, guilt and despair about what they call 'loss of faith.' But serious doubt is confirmation of faith. It indicates the seriousness of the concern, its unconditional character." 27 Rees is not completely convinced by this assertion, however. He wonders, "Should we describe, for example, the obsession of the drug addict as an ultimate concern and therefore

\footnotetext{
${ }^{25}$ Tillich, Dynamics of Faith, 21.

${ }^{26}$ Ibid., 21.

${ }^{27}$ Ibid., 22.
} 
faith?"28 Rees suggests that it is not only the structure of ultimate concern but also the content that determines faith. ${ }^{29}$ He goes on to say, "We might also question Tillich's assumption that all people do in fact have something which is for them of life-or-death significance, an ultimate concern. ${ }^{30}$ Ultimately, though, Rees finds value in Tillich's universal application of faith, even if it is not a perfect system. Rees appreciates that "there can be no hard-and-fast division ... between the contents of true and of idolatrous faiths." 31 Tillich sees the faith in the drug addict as clearly as he sees the idolatry of the Christian. Rees concludes, "To allow for this essential ambiguity in the nature of faith is not therefore a weakness, but a strength of the concept of faith as ultimate concern."32 Therefore, when someone claims to have lost her faith, there are at least three possibilities for what has actually happened. First, the content of that person's faith may have changed. Second, although that person may have a true faith in God, some of her beliefs might not match church teaching. Last, the person may just be experiencing a greater than usual awareness of the existential doubt and risk involved in faith. None of these, however, is actually a loss of faith, although one may feel like it is.

\section{Tillich On Apologetics}

In order to understand Tillich's concept of faith, one must understand Tillich's concept of existential doubt. Likewise, an understanding of existential doubt is also essential for understanding apologetics. Although Tillich does not speak explicitly about apologetics as frequently as he speaks about faith and doubt, he sees his whole system generally as apologetics. Furthermore, by understanding the role of existential doubt, one can develop a practical

\footnotetext{
${ }^{28}$ Rees, Wrestling With Doubt, 96.

${ }^{29}$ Ibid., 97.

${ }^{30}$ Ibid., 96.

${ }^{31}$ Ibid., 96-97.

${ }^{32}$ Ibid., 97.
} 
apologetics out of the elements of Tillich's apologetic method. In order to discover these elements, one must turn first to what Tillich has written regarding apologetics, including his theological method and the role of the church in apologetics. Existential doubt will continue to play a role in both these sections. After examining Tillich's thought on apologetics, five guidelines for a practical dimension of Tillichian apologetics will be developed in light of his concept of existential doubt.

\section{Tillich's Apologetic Method}

Tillich calls his theology an "answering theology," which means theology must answer the questions of humanity. ${ }^{33}$ He writes, "Apologetics, therefore, is an omnipresent element and not a special section of systematic theology." ${ }^{34}$ For Tillich, apologetics is important for all those who have placed their faith in an idol. Tillich claims that "arguments are needed, because they may serve to break through the intellectual walls of skepticism as well as of dogmatism with which the churches' critics protect themselves against the attacks of the Spiritual Presence."35 Apologetic explanations open up both the skeptic and the dogmatist to the Holy Spirit. Nevertheless, apologetics must not make a god of itself by forgetting its limits. Tillich warns that "systematic theology must also stress its own limits as theoretical apologetics as well as the limits of even the most skillful apologetic practice. The acknowledgement of its own limits is itself an element in the apologetic function." ${ }^{36}$ Tillich is consistent in applying his Protestant principle even to his own work.

Tillich embeds apologetics in his systematic theology through the method of correlation. The method of correlation begins with one's existential questions, in other words, one's ultimate

\footnotetext{
${ }^{33}$ Tillich, Systematic Theology Volume One, 31.

${ }^{34}$ Ibid., 31.

${ }^{35}$ Paul Tillich, Systematic Theology: Three Volumes in One, vol. 3 (Chicago, University of Chicago Press, 1967), 195.

${ }^{36}$ Ibid., 195.
} 
concern. The answer seeks to directly speak to the existential doubt that one feels. The answer, God, is the only possible truly ultimate content for our faith. ${ }^{37}$ Tillich provides several examples to illustrate how the questioning and answering works:

If the notion of God appears in systematic theology in correlation with the threat of nonbeing which is implied in existence, God must be called the infinite power of being which resists the threat of nonbeing. . . If anxiety is defined as the awareness of being finite, God must be called the infinite ground of courage. . . . If the notion of the Kingdom of God appears in correlation with the riddle of our historical existence, it must be called the meaning, fulfillment, and unity of history. ${ }^{38}$

By formulating the answer in a way that resonates with the asker of the question, Tillich hopes to take the cultures and real situations of humanity seriously.

John S. Morris identifies this respect for cultural questions of the moment as both the strength and weakness of Tillich. He writes, "It is a part of the genius of Tillich that he is aware of the need to adapt the message to the needs of a particular time and a particular culture by means of the method of correlation. The question is, however, whether he is assuming too much in making the existentialist philosophy the only valid analysis of our present culture."39 Nevertheless, the possibility of other apologetic techniques does not diminish the value of Tillich's contribution. In The World Situation, Tillich writes, "The Christian message to the contemporary world will be a true, convincing, and transforming message only insofar as it is born out of the depths of our present historical situation." 40 Yet, he continues by admitting, "No single thinker or theological movement can plumb the depths of the world situation."41 Tillich accepts the charge of cultural particularism and suggests that all apologetics are necessarily limited in this way.

\footnotetext{
${ }^{37}$ Tillich, Systematic Theology Volume One, 64.

38 Ibid., 64.

${ }^{39}$ John S. Morris, “The Philosophical Basis of Tillich's Apologetic Theology," The Christian Scholar 47, no. 3 (1964): 241.

${ }^{40}$ Tillich, The World Situation, 48.

${ }^{41}$ Ibid., 48.
} 


\section{Church Communities}

The church, understood as the Christian community of faith made up of individual churches and smaller faith communities, is the place where both apologetics and systematic theology in general are done. In regards to apologetics, Tillich writes, "The church . . is continually being asked questions about its nature which it must answer, and that is what apologetics means: the art of answering." 42 Tillich continues, "Apologetics must be cultivated by the churches; otherwise they will not grow but will diminish in extension and increasingly become a small, ineffective section within a dynamic civilization." ${ }^{43}$ Logically, if apologetics is taking place in churches, those with doubts should also be in those same churches. Tillich believes whole-heartedly that even those with serious doubts should be welcomed into faith communities. Even as a young adult, Tillich already saw a place for doubt within faith communities. Tillich recalls in a lecture what he said to his fraternity in 1904, "The individual person doubts, or he does not doubt, and his doubt might even be very radical, but if he takes very seriously the problem of his doubt and his faith, and struggles with the problem of the loss of faith in him, then he is a member of our fraternity." ${ }^{44}$ Later in life, Tillich uses the term "existential doubt" in place of "radical doubt" and maintains that doubters have not actually lost their faith. In Dynamics of Faith, Tillich explains why participation in a faith community is not only permissible but even to be encouraged for the doubter:

The act of faith, like every act in man's spiritual life, is dependent on language and therefore on community. For only in the community of spiritual beings is language alive. Without language there is no act of faith, no religious experience! . . Only as a member of such a community (even if in isolation or expulsion) can man have a content for his ultimate concern. Only in a community of language can man actualize his faith. ${ }^{45}$

\footnotetext{
${ }^{42}$ Tillich, Systematic Theology: Three Volumes in One, vol. 3, 195.

${ }^{43}$ Ibid., 195. Similar ideas can be found in Tillich, Systematic Theology Volume One, 48.

${ }^{44}$ Paul Tillich, Perspectives on 19th and 20th Century Protestant Theology, ed. Carl Braaten (New York: Harper \&Row, 1967), 154.

${ }^{45}$ Tillich, Dynamics of Faith, 23-24.
} 
In order for a community of faith to admit those who doubt, or even to allow for authentic faith in God at all, the church must leave room for risk and courage. The existential doubts of the faith community should be directed, but not extinguished. Tillich warns that if church leaders present beliefs as infallible, believers "may have to struggle within themselves about their subjection; but after they have made the decision, no doubt can be admitted by them about the infallible statements of the authorities." ${ }^{46}$ By extinguishing doubt, these church leaders will have led their faith community to idolatry because in this act, "something preliminary and conditional - the human interpretation of the content of faith from the Biblical writers to the present receives ultimacy and is elevated above the risk of doubt." ${ }^{47}$ Without the presence of existential doubt the community of faith is defenseless against idolatry because doctrine about God will be made the object of ultimate concern instead of God. Again, the spiritual community cannot be a faith community without doubt, risk, and courage.

\section{Five Principles For A Practical Tillichian Apologetics}

The first section developed Tillich's understanding of faith and existential doubt. The second section highlighted Tillich's writings that explicitly or implicitly relate to apologetics. Now, with an understanding of Tillich's writings on faith, doubt, and apologetics, practical guidelines for apologetics based on Tillich's thought can be proposed. Using existential doubt as the grounding center for this apologetics, five guidelines for carrying out apologetic work can be developed in line with Tillich's writings. It must be noted, however, that what Tillich provides in his own writing is a theoretical apologetics more than a practical apologetics. ${ }^{48}$ While Tillich

\footnotetext{
${ }^{46}$ Ibid., 28.

${ }^{47}$ Ibid., 28.

${ }^{48}$ Tillich, Systematic Theology: Three Volumes in One, vol. 3, 195.
} 
sheds light on the way apologetics is meant to function, he does not necessarily mean for apologetics to be performed exactly as stated in a pastoral situation. Although the five guidelines aim to make Tillich's apologetics more explicit and practical, attention to the specific pastoral needs of a given community is still necessary.

The first guideline in this Tillichian apologetics is that apologetics needs to include those who already identify as Christians as well as non-Christians in its audience. Non-Christians, the typical audience for a Christian apologetics, are encouraged to enter into the fold. Christians, though, also need apologetics because they are also prone to clinging to idols. Many Christians enter the church hoping for peace and stability, and while the church can offer that, even the Christian cannot escape the questions of human existence. Christians need to be challenged to move beyond a childish feel-good mentality toward a place where they can grapple with ultimate concerns that are truly ultimate. They also need to be taught that sitting with doubt and realizing that one does not know God as well as one thought, is a part of being a Christian. Tillich's apologetics dispels the myth that comfort and complacency are the highest good while simultaneously comforting those Christians who have struggled with doubt. Furthermore, Tillich blurs the line between Christian and non-Christian so much that the distinction hardly has meaning. Both have an ultimate concern and therefore faith. Both doubt the content of their ultimate concern will come through for them. Both are prone to idolatry. This ambiguity is particularly beneficial for apologetics in the $21^{\text {st }}$ century because it is rare to ever have a venue consisting solely of either Christians or non-Christians. Society in general is mixed, and if the quotes above from Tillich and Bloesch are correct, then due to the increasing secularity of churches, even those that attend church services are a mixed bunch. 
The second guideline is to end the suppression of doubt in order to break down idols. For Tillich, apologetics is not a matter of bringing faith to the faithless because everyone has faith in something. Therefore, the goal of apologetics is to break down idols, misplaced faith. This is part of the genius of Tillich's thinking. Instead of starting with an explicitly Christian message, the apologist begins with the ultimate concerns of her audience. As soon as one turns the conversation to ultimate concerns, existential doubt, risk, and courage surface as well. The apologist questions whether these ultimate concerns are truly ultimate. If they are not, are they worth the risk? The idols begin to crumble at this point. Then, the apologist, relying on the Protestant principle, suggests that anything easily definable, able to be possessed, or imposed by another authority cannot really be ultimate. This could include one's nation, drugs, success, science, a lover, doctrines, creeds, or proofs. Now the idols have collapsed as Tillich believes all idols finally will. This, of course, is when the message of Christ and of the God who is bigger than creeds and hierarchies is introduced through the method of correlation. One's ultimate concern is examined, and God is expressed as the answer to that concern. Ideally, God then replaces the previous false content of one's ultimate concern. While this could be a difficult process, it is also hopeful and offers an ultimate concern that is worth the risk of faith.

The third guideline is that apologetics should affirm faith without aiming to rid one of doubt. This is impossible if the definition of faith is accepting something as true without sufficient evidence. One cannot accept something and still doubt it. However, Tillich's understanding of faith as ultimate concern does allow for doubt. The doubt keeps one from clinging to idols. It is a reminder that if one's ultimate concern fails, the meaning of one's life will also be destroyed. The aspect of doubt in faith gives faith the serious tone that a relationship with God requires. Nevertheless, one should not be continually incapacitated by existential 
doubt. Although an aspect of faith, doubt is not the whole story. Courage is meant to counter doubt to create a balance that keeps one alert.

The fourth guideline is that apologetics should bring Christians and non-Christians into faith communities. Tillich here understands the value of 'talking it out.' Without a community interested in the discussion of ultimate concerns, one cannot develop a language to talk about one's experience. These faith communities consist of various overlapping groupings and sizes. They include individual parishes as well as the Christian church as a whole. The defining characteristic is simply people, Christian or not, talking about their ultimate concerns. Scripture offers the same wisdom in the Gospel of Matthew which says, "For where two or three are gathered in my name, I am there among them." ${ }^{, 49}$ Since one comes to understand oneself through language and self-expression, it is perhaps impossible to have a conscious faith in God, or in anything, without telling someone else about it.

The fifth guideline is that faith communities will continue the work of apologetics. These communities can serve one through all the steps on the way to true faith in God. First, communities help one discover that one is, in fact, ultimately concerned about something. Next, a faith community can help one identify potential idols. The support of a community is essential for navigating through the doubt and risk of accepting a new content for one's faith. The faith community can be a source of courage, and the members can serve as witnesses that faith is worth the risk. Finally, these communities have an important role for the future of apologetics. Tillich suggests that it is impossible to lose one's faith. Yet this is the language commonly used. The church needs faith communities to develop a new vocabulary that better suits the experience of existential doubt. If it is only through language that one can understand one's life, an effective vocabulary is an essential step toward a faith that endures the forces of secularity in the

\footnotetext{
${ }^{49}$ Matthew 18:20 (NRSV).
} 
world and in the church. If religion becomes irrelevant to contemporary society, the blame must fall on a vocabulary that is inadequate for the contemporary experience of God.

\section{Concluding Remarks}

Apologetics must converse with doubt rather than dismiss doubt. Tillich's writings offer a relevant interpretation of faith and doubt with the strength to withstand secularity.

Acknowledging the role of doubt in faith is not only comforting for Christians who have struggled with doubt, but also expands faith to a universal phenomenon. When combined with Tillich's writings on the method of correlation and the church, a theoretical apologetics results. From this foundation, five guidelines can be derived to make Tillich's apologetics more explicit and practical. These five guidelines circle tightly around Tillich's concept of existential doubt.

A Tillichian apologetics:

1. Includes both Christians and non-Christians in its audience because both are at risk of idolatry

2. Ends the suppression of doubt in order to break down idols

3. Affirms faith without aiming to rid one of doubt

4. Brings Christians and those who are not yet Christian into faith communities

5. Encourages faith communities to continue the work of apologetics

One of the benefits of making Tillich's theoretical apologetics more explicit is the potential for a practical apologetics to grow out of it. By understanding Tillich's thought and following the five guidelines above, one can adapt Tillich's insights to actual pastoral situations. This is of especially great value for those who recognize their struggle with doubt and feel guilty for their perceived lack of faith. Tillich's apologetics expertly maintains a sensitivity to deeply troubling questions while resisting the temptation to provide unsatisfactory, easy answers. As a result, Tillich helps move the church toward true faith in God. 